\title{
Maternal and Fetal Toxicity of Carisoprodol Drug (Somadril Compound) on Pulmonary Tissues of Albino Rats
}

\author{
Nahed Mohamed Mansour Emam \\ Zoology Department, Faculty of Science, Al-Arish University, Egypt \\ E-mail: nahedemam2018@yahoo.com
}

Received: Sep. 16, 2019 Accepted: Oct. 31, 2019

doi:10.5296/jbls.v11i1.15459 URL: https://doi.org/10.5296/jbls.v11i1.15459

\begin{abstract}
Carisoprodol is a common muscle relaxant indicated as adjunctive therapy in acute, painful musculoskeletal cases. This current study aimed to investigate the histopathological, histochemical and immunohistochemical effects in the lung tissue of the pregnant rats and their fetuses after carisoprodol treatment. The present study was applied on twenty seven pregnant female rats and they were randomly divided into three groups (nine pregnant female rats in each group). Rats of the first (control) group were administered oral doses of distilled water. Rats of the second (S1) and third groups (S2) were administered oral doses of carisoprodol in the distilled water equivalent to $10.8 \mathrm{mg}$ and $21.6 \mathrm{mg} / 100 \mathrm{~g}$ body weight/day respectively for fifteen days from the six to the twenty day of gestation. Several histopathological, histochemical and some immunohistochemical changes were studied to detect the pathological changes. Maternal and fetal pulmonary tissues of both treated groups showed numerous degenerative changes post-treatment with carisoprodol, the severity of these changes was more obvious in the fetal lung tissue of both groups. Also, carisoprodol treated rats showed a marked increase in caspase- 3 content in the maternal and fetal pulmonary tissues. Treatment of pregnant rats with carisoprodol drug led to numerous dystrophic changes in both maternal and fetal lung tissues.
\end{abstract}

Keywords: maternal, fetal, lung, carisoprodol, histopathology, histochemistry, caspase-3

\section{Introduction}

Carisoprodol is a widely prescribed skeletal muscle relaxant indicated as adjunctive therapy in acute, painful musculoskeletal conditions, abuse of carisoprodol has grown considerably in recent years (Ralph et al. 2008). Carisoprodol is a centrally acting muscle relaxant, it with a high abuse potential leading to central nervous system depression and may result in 
symptoms that are more difficult for providers to treat (Kathy et al. 2017). Moreover, carisoprodol drug is available as somadril compound which contains paracetamol $160 \mathrm{mg}$, caffeine 32mg and carisoprodol 200mg (Bramness et al. 2008). The drug is found in markets by a diversity names (Soma, Sodol, Somalgit, Vanadam, Sonoma, Scutamil, Carisoma, Somacid, Mio Relax, Relacton-C, Relaxibys, Rela and Soridol) as reported with Reeves et al. (2012). Soma is a neutral crystalline powder with white color and it is a chemical derivative of meprobamate with an aliphatic dicarbamate. It is soluble in many organic diluents, insoluble in vegetable oils, but soluble in water (Rust et al. 1993). Carisoprodol $250 \mathrm{mg}$ is equally effective and better tolerated than carisoprodol $350 \mathrm{mg}$. Generally, both doses are generally well tolerated (Simon et al. 2010). Carisoprodol and meprobamate are commonly encountered drugs in forensic toxicology (Robertson \& Marinetti, 2003). Carisoprodol (Soma) and its metabolite meprobamate lead to generalized CNS depression, which may change the perception of pain. The specific mechanisms of carisoprodol include blockade of inter neuronal activity and depression of the polysynaptic neuronal transmission in the spinal cord and reticular formation of the brain (Kumar \& Dillon, 2016). Carisoprodol over dosage produces symptoms similar to those of meprobamate over dosage and may include shock, coma, respiratory depression and very rarely death (Mclntyre et al., 2012). Carisoprodol and its active sedative hypnotic metabolite, meprobamate are gamma aminobutyric acid receptor indirect agonists with chloride ion channel conduction of central nervous system (Witenko et al. 2014). Whereas, the carisoprodol drug is metabolized by the liver and excreted by the kidneys, the drug should be used with special caution in patients with impaired hepatic or renal functions (Naresh et al. 2013). According to the previous studies, carisoprodol treatment of the pregnant rats caused severe variations in the esophageal tissue of fetuses, highly thickened mucosal layer with lots of vacuolated cells and highly distorted sub mucosal layer, discontinuous and ruptured muscle fibers in the muscularis layer with ruptured serosa after carisoprodol treatment (Abd Rabou, 2019). Also, treated rat with Somadril showed testicular vacuolation and degeneration and lessening in spermatozoa within the lumen and loss in normal architecture of the seminiferous tubules(Anwar et al. 2017). Moreover, carisoprodol treatment of pregnant rats caused numerous severe degenerative changes in hepatic tissue of pregnant animals and their fetuses which included highly congested blood vessels, numerous hemorrhagic areas and necrotic areas (Abouel-Magd, 2018). Pulmonary tissue injury caused by certain drugs and some toxic chemicals has been recognized as a toxicological problem. Also, tissues toxicity is one of most common aliment lead to serious effects ranging from intensive metabolic disorders to even mortality (Ballet, 2015). No more available studies were obtained which concerning with histopathological changes in the pulmonary tissues post-carisoprodol treatment. Also, there are limited literatures on clinical profile of subjects abusing carisoprodol so; this study aimed to investigate the effect of carisoprodol drug on both maternal and fetal lung tissue of rats with two different doses.

\section{Material and Methods}

\subsection{Drug}

Carisoprodol is taken for healing the painful and discomfort associated with acute musculoskeletal cases, it is obtained from Mina Pharm for Pharmaceuticals and Chemical 
Industries, Cairo, Egypt. Carisoprodol compound was obtained as tablets of a combination product containing three components, carisoprodol $200 \mathrm{mg}$, caffeine $32 \mathrm{mg}$ and paracetamol $160 \mathrm{mg}$.

\subsection{Animals}

Adult albino rats (Sprague dawely strain) were used in this experiment, with average weight 140-180g. They were taken from the animal house of El -Nasr Pharmaceutical Chemicals Co. rats were caged separately, males in cages and females in others. All rats were housed in a quite non stressful environment for 10 days before beginning the current study. They were offered water ad libitum and normal rat chows during the experiment. The females were mated in the proportion of two females for one male overnight. A vaginal smear was taken each morning for check of the presence of plug or sperms in the vagina. Zero day of pregnancy was considered to be the day on which plug or sperms were found in the vagina.

\subsection{Experimental Design}

Twenty seven pregnant female rats were randomly divided into three groups (nine pregnant female rats in each group).

Group 1 (C): control rats: normal healthy rats orally administered with distilled water doses.

Group 2 (S1): pregnant female rats were orally administered with carisoprodol in distilled water at a dose of $10.8 \mathrm{mg} / 100 \mathrm{~g} \mathrm{~b}$.wt. /day for 15 days respectively from the 6 th day to the 20th day of gestation (Abouel-Magd, 2018).

Group 3 (S2): pregnant female rats were orally administered with carisoprodol in the distilled water at a dose of $21.6 \mathrm{mg} / 100 \mathrm{~g} \mathrm{~b}$. wt. /day for 15 days respectively from the 6th day to the 20th day of gestation (Abouel-Magd, 2018).

The dose for rats was calculated according to the method Paget and Barnes (1964) formula on the basis of the human dose. All the three previous groups were sacrificed after 24 hours from the last drug administration.

\subsection{The Histopathological Examination}

All pregnant rats were sacrificed and small samples of lung tissues from mothers and their fetuses were picked out for the histological and histochemical studies. Sections of lung tissues form mothers and their fetuses were prepared and stained with hematoxylin and eosin stain (Bancroft and Gamble, 2008). Collagen fibers were stained by using Mallory's trichrome stain method (Pearse, 1977), polysaccharides were detected by using periodic acid Schiff's (PAS) reagent (Drury \& Wallington, 1980). Total proteins were detected by using mercuric bromophenol blue method (Pearse, 1972). DNA was detected by using Feulgen reaction (Kiernan, 1981). Amyloid protein was detected according to Congo red technique (Valle, 1986).

\subsection{Immunohistochemistry Examination}

Immunohistochemical detection of caspase- 3 was performed by using anti caspase 3 Primary 
antibody (Labvision, Neomarkers, USA) according to the protocol described by Abdel-Wahab \& Metwally (2015) using a streptavidin-biotin system. Positive reaction for caspase 3 was visualized as brown coloration of the cytoplasm in treated cells.

\subsection{Statistical Analysis}

The present results were expressed as Mean \pm SE. Data were analyzed by using the Statistical Package (SPSS) program. Significant differences between treatment means were determined by student T-test. The data were presented as mean $\pm \mathrm{SE}$ and $\mathrm{P} \leq 0.05$ was considered statistically significant. Image analysis: the optical density (pexil) of the lung tissue in the present study was analyzed by using image pro. Program.

\section{Results}

\subsection{Lung of the Pregnant Rats}

\subsubsection{The Histopathological Observations}

Stained sections of lung from a control pregnant rat showed normal alveoli with their thin inter alveolar septae lined with simple squamous epithelium and clear alveolar sacs. Bronchioles appeared with their pseudo stratified ciliated columnar epithelial cells. Peri-bronchiolar blood vessels and capillaries were normal in appearance (Figs. 1\& 2). Lungs of pregnant rats of S1, S2 groups indicated extensive tissue damage, alveolar hemorrhage, severely damaged bronchioles and cellular infiltration in the lung tissues. The histopathological changes increased in their severity in a dose dependent manner. Maternal lung tissue of S1 group showed numerous necrotic areas, alveoli with thickened alveolar septae, narrow alveolar sacs, highly thickened walls of blood vessels, most of them were congested with hemolysed blood cells inside them. Most bronchioles showed thickened walls, some of them contain debris of degenerated cells; others contain hemolysed blood cells and granulomatous areas in the lung tissue (Figs. 3- 6). Lung tissue of pregnant rats of S2 group showed delaminated epithelium of most bronchioles which lost the normal architecture. Some bronchioles contained irregular folds of the bronchial mucosa and irregularly distributed muscle fibers in the bronchial walls. Most of bronchioles contained hemolysed blood cells or debris of degenerated cells. Granulomatous areas, numerous necrotic areas, highly congested arteries with highly thickened and corrugated walls, highly congested blood vessels and cellular infiltration were commonly appeared in the lung tissue (Figs. 7- 12). Sections of the lung tissue of maternal control group showed slight collagen fibers which were supporting walls of blood vessels, bronchioles and alveolar septae (Fig. 13). Increased collagen fibers were demonstrated in the highly thickened and corrugated arterial and bronchial walls in the interstitium between them and also in the granulomatous areas of lungs of rats of S1, S2 groups in a dose dependent manner (Figs.14-17). The brightly stained red blood cells were clearly appeared inside the highly congested blood vessels and fatty cells inside the lung tissue were in common appearance in the lung tissue of S1 group (Fig-16).

\subsubsection{The Histochemical Observations}

Moderately distributed PAS +ve materials were appeared in the lung tissue of control 


\section{MInstitute ${ }_{\text {Int }}^{\text {Macrothink }}$}

Journal of Biology and Life Science ISSN 2157-6076 2020, Vol. 11, No. 1

pregnant rat which was indicated by moderate staining affinity of the bronchial walls and alveolar septae (Fig. 18). Increased staining affinity of PAS+ve materials was appeared in the bronchioles with thickened walls, walls of arteries and the alveolar septae of rats of S1,S2 groups with moderately stained granuloma areas (Figs. 19-23). Lung tissue of rats of the control group showed moderate distribution of total protein content in the bronchial walls, alveolar septae and walls of the blood vessels (Fig. 24). Highly increased staining affinity of total protein was noticed in the corrugated and thickened walls of the pulmonary bronchioles, blood vessels and alveolar septae of rats of S1, S2 groups (Figs. 25-29). Lung tissue of the control rat showed a slight deposition of amyloid $\beta$ in the lung tissue (Fig. 30). Highly increased accumulation of amyloid $\beta$ materials was detected in the highly thickened and corrugated walls of bronchioles, arteries and alveolar septae in the lung tissue of S1, S2 groups (Figs. 31-35). Lung tissue of the control rats showed moderate distribution of DNA in the form of magenta color granules. A noticeable decrease in DNA content was detected in the nuclei of the highly thickened walls of bronchioles, arteries and alveolar septae and some nuclei of degenerated cells inside the bronchial lumens of lungs of rats of S1, S2 groups.

\subsubsection{Immunohistochemical Observations}

Lung tissue of the control rats showed negatively stained caspase- 3 (Fig. 36). Lung tissue of pregnant rats from S1, S2 groups showed increased amount of caspase- 3 indicated by the dense brown stain when compared with the normal control group (Figs. 37, 38).
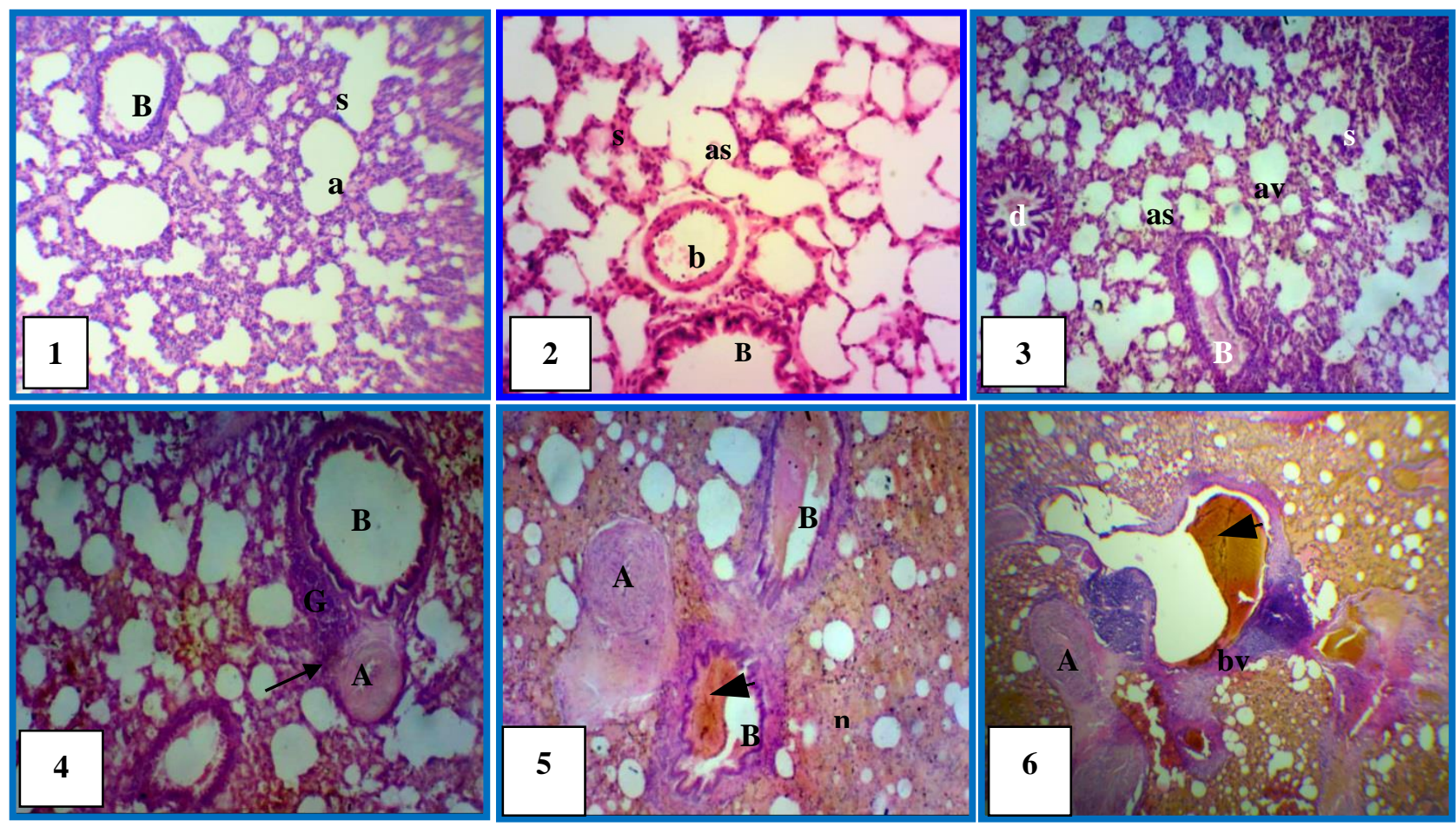

Figures 1-6. Photomicrographs of lung tissue of the pregnant rats of control and S1- treated group stained with hematoxylin and eosin

Figs.1\&2: showing lung tissue of a control pregnant rat with normal alveolar sacs (as), inter alveolar septae (s) lined with simple squamous epithelium, bronchioles (B) with their 


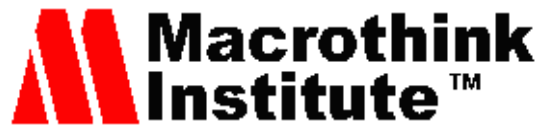

Journal of Biology and Life Science ISSN 2157-6076 2020, Vol. 11, No. 1

pseudo-stratified ciliated columnar epithelial cells, peri-bronchiolar blood vessels (bv) (1X100, 2X 200).

Figs. 3-6: showing lung tissue of maternal rats of S1 group with many alveoli (av) with thickened alveolar septae (s), narrow alveolar sacs (as), highly thickened walls of blood vessels (bv), most of them are congested with hemolysed blood cells (arrow heads). The bronchioles (B) appeared with highly thickened walls, some of them contain debris of degenerated cells (d), others contain hemolysed blood cells (arrow heads) and granulomatous areas $(\mathrm{G})$ in the lung tissue with cellular infiltration in the lung tissues (arrow), highly thickened arterial walls with narrow lumens (A) and numerous necrotic areas (n) (X 100).
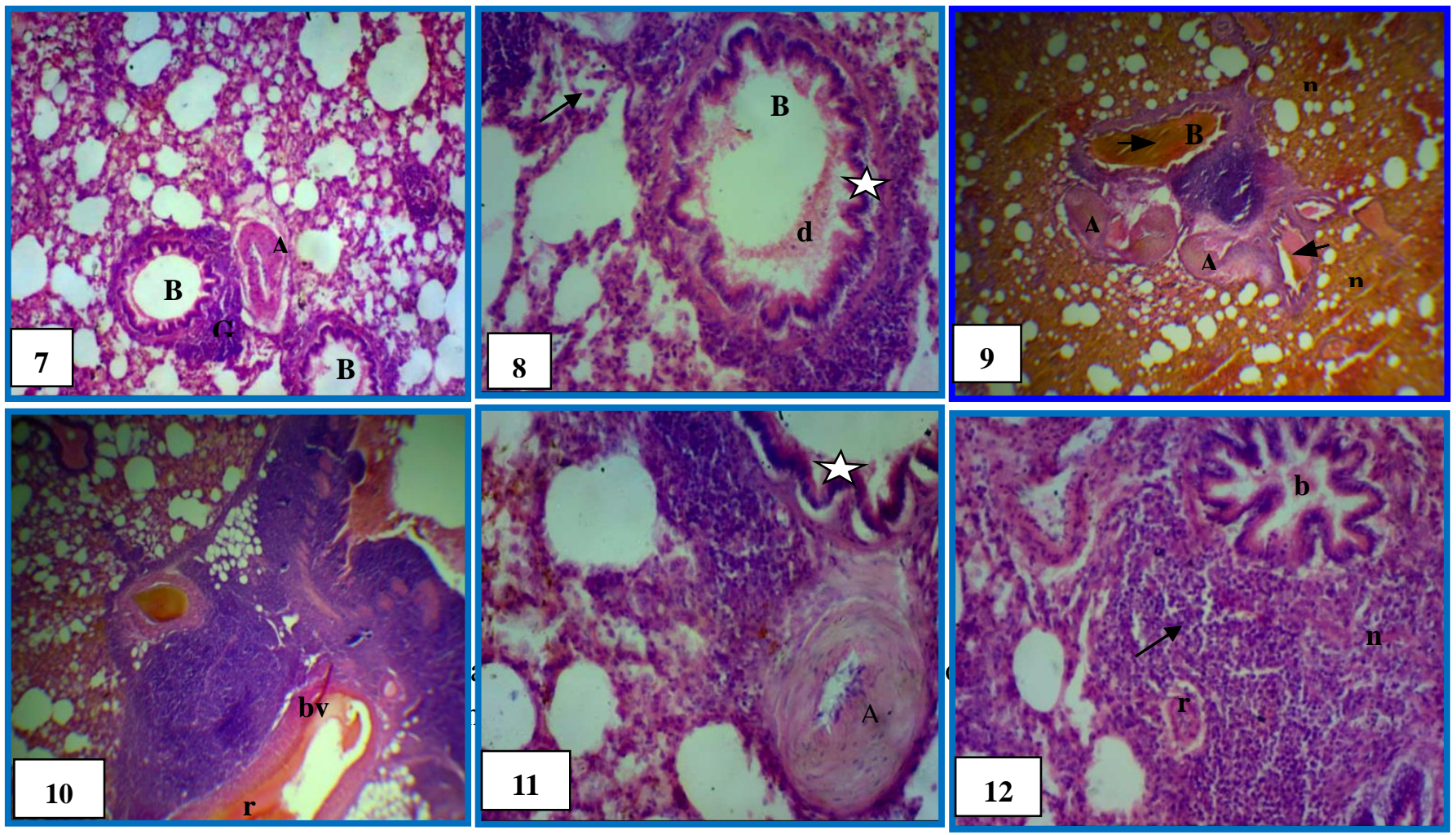

Figs.7-12. Showing lung tissue of pregnant rats of S2 group stained with hematoxylin and eosinNotice: highly delaminated epithelium of the bronchiole which lost their normal appearance $(*)$

Some bronchioles (b) contained irregular folds of the bronchial mucosa and irregularly distributed muscle fibers in the bronchial walls. Most of bronchioles (B) contain hemolysed blood cells (arrowheads) or debris of degenerated cells (d). Granulomatous areas (G), numerous necrotic areas (n), highly congested arteries with highly thickened and corrugated walls (A) were detected. Also, the brightly stained RBCs (r) inside the highly congested blood vessels (bv) and cellular infiltration in the lung tissue (arrow) were commonly appeared $(7,9,10 \mathrm{X} 100 \& 8,11,12$ X 200) 


\section{$\triangle$ Macrothink}
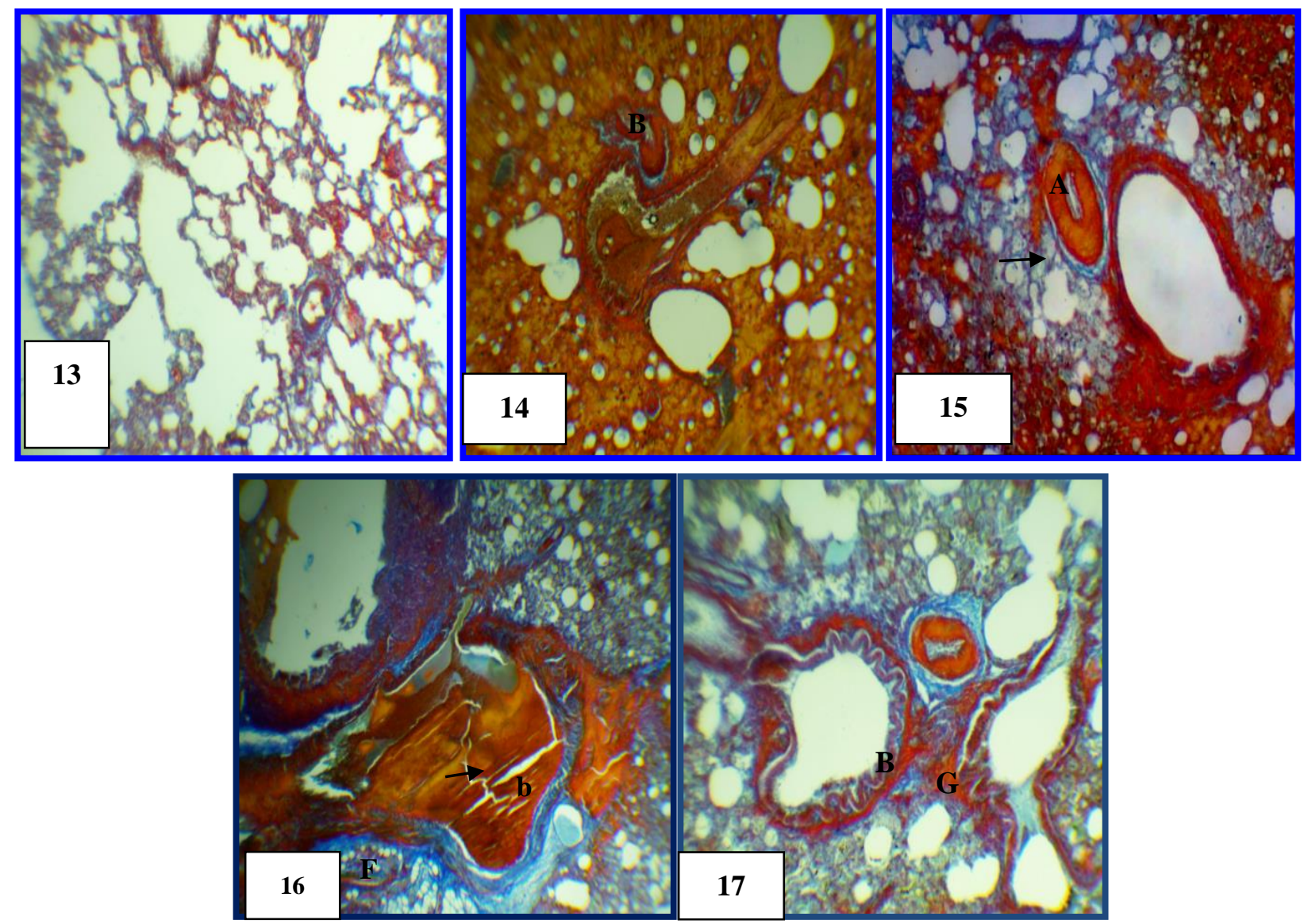

Figures 13-17. Photomicrographs of lung tissue showing distribution of the collagen fibers in the lung tissues of the control and treated groups stained with Mallory's trichrome stain

Fig.13: lung tissue of a control rat showing slightly thin collagen fibers support walls of bronchioles, blood vessels and alveolar septae (X 100). Figs.14-15: lung tissue of rats of S1 group showing increased collagen bundles in the highly corrugated and thickened walls of arteries (A), bronchiole (B) and in the interstitium of the lung tissues (arrow) (X 100). Figs.16-17: lung tissue of rats of S2 group showing highly increased collagen bundles in the highly thickened and corrugated walls of arteries (A), bronchioles (B), in the interstitium between them and in the granulomatous areas $(\mathrm{G})$. Notice: brightly stained RBCs (arrow) inside the highly congested blood vessels and fatty cells (F) inside the lung tissue (X 200). 


\section{$\triangle$ Macrothink}
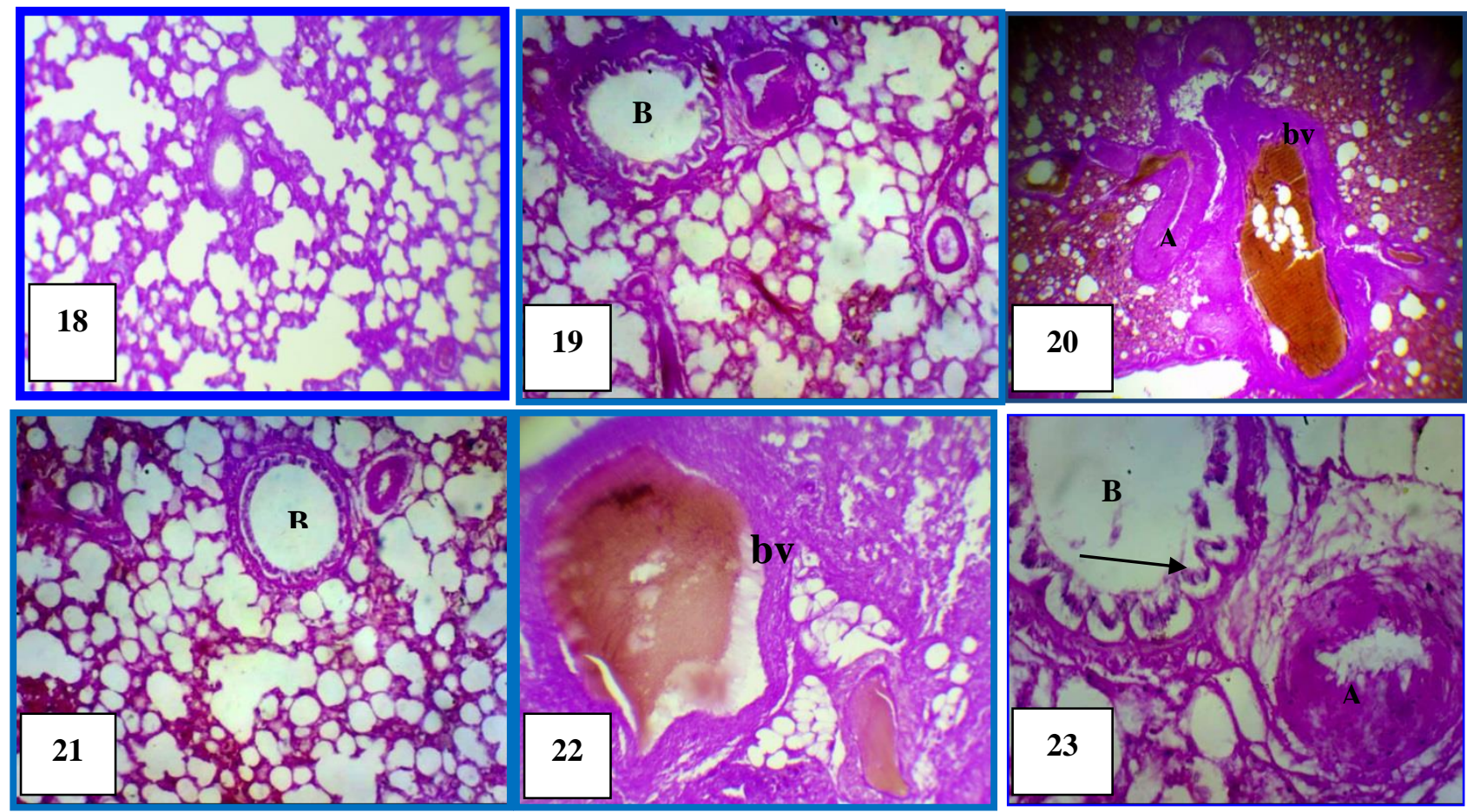

Figures 18-23. Photomicrographs of lung tissue showing distribution of PAS +ve materials in the lung tissues of the control and treated groups (PAS reaction)

Fig.18: lung tissue of control rat showing moderately stained PAS +ve materials in walls of bronchioles and alveolar septae (X 100). Figs. 19, 20: lung tissue of rats of S1 group showing increased PAS +ve materials in the thickened walls of arteries, bronchioles and alveolar septae. Notice: thickened arterial walls (A) with deeply stained PAS +ve materials (X 100). Figs. 2123: lung tissue of S2 group showing highly increased staining affinity of polysaccharides in the highly thickened walls of the congested blood vessels, alveolar septae and bronchioles in the lung tissue with delaminated and distorted epithelial walls of the bronchioles (arrow) (21, 22 X 100; 23 X200). 


\section{$\triangle$ Macrothink}
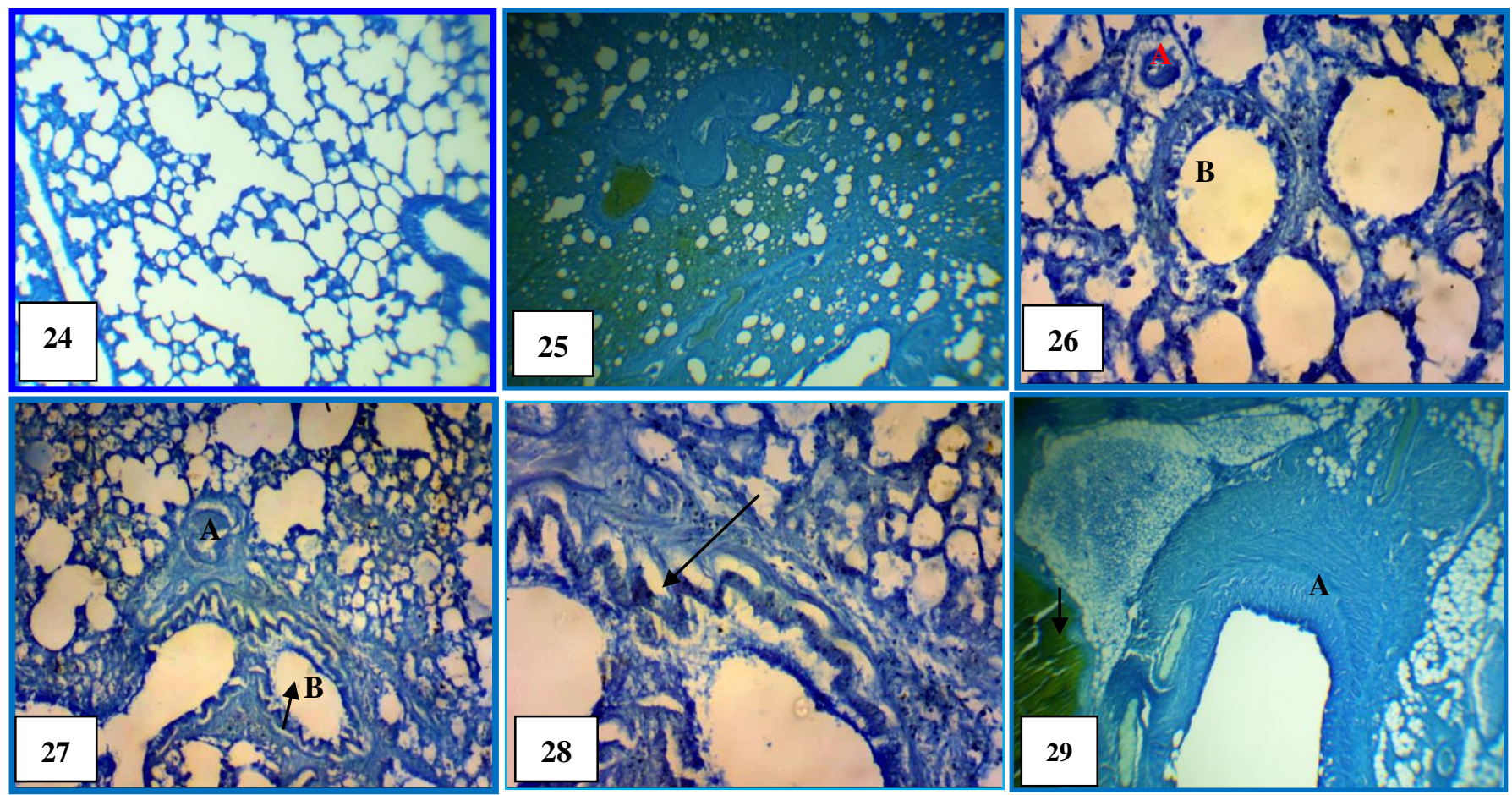

Figures 24-29. Photomicrographs of lung tissue showing total protein distribution in the lung tissue of the control and treated groups stained with Mercury bromophenol blue

Fig.24: lung tissue of a control rat showing moderately stained total protein in walls of the bronchioles, alveolar septae and blood vessels (X 100). Figs.25-26: lung tissue of rats of S;1 group showing increased total protein in the thickened and distorted walls of the bronchioles, blood vessels and alveolar septae (X 100). Figs.27-29: lung tissue of rats of S2 group showing highly increased total protein in the arterial wall, inside and outside the corrugated wall of bronchiole (B), granulomas area and in the thickened alveolar septae. Notice: the darkly stained hemosiderin granules (short arrow) inside the thickened arterial walls (A) with deeply stained total protein and highly distorted and delaminated epithelial walls of the bronchioles (long arrow). (X100) 


\section{MInstitute ${ }_{\text {Mnk }}^{\text {Macrothink }}$}
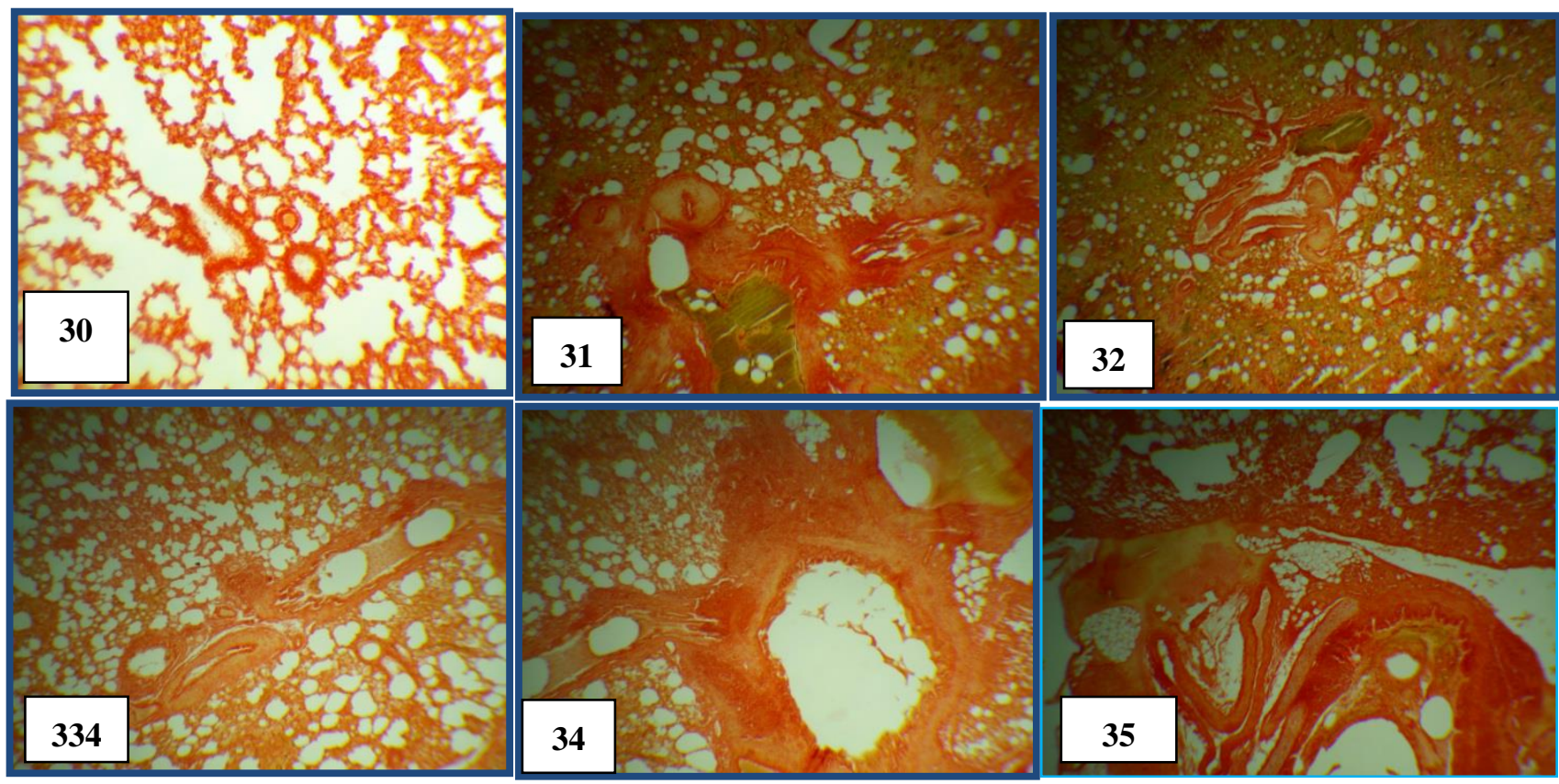

Figures 30-35. Photomicrographs of lung tissue showing distribution of amyloid $\beta$ in the lung tissue of control and treated groups stained with Congo red stain

Fig.30: lung tissue of a control maternal rat showing a slight deposition of amyloid $\beta$ in the lung tissue (X 100). Figs. 31, 32: lung tissue of rats of S1 group showing increased accumulation of amyloid $\beta$ material in the lung tissue. (X 100). Figs. 33-35: lung tissue of a maternal rat of S2 group showing highly increased accumulation of amyloid $\beta$ material in the highly thickened walls of bronchioles, alveolar septae and arteries in the tissue (X 100).
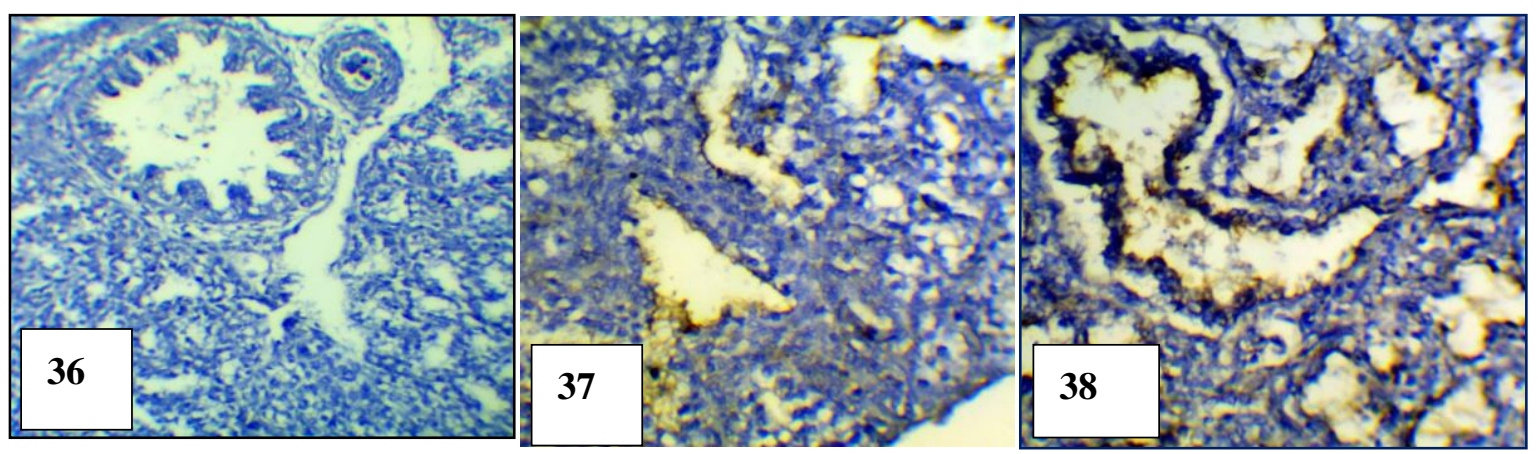

Figures 36-38. photomicrographs from maternal lung tissue of rats of the control, S1, S2, groups stained with Caspases-3- immune-staining

Fig. 36: maternal lung tissue of control rat showing negatively stained caspase-3 (X 200). Figs. 37-38: maternal lung tissue of rats of S1 and S 2 group showing widespread reaction for positive immunoreactivity for anti-caspase- 3 indicated by less dense brown staining affinity in the lung tissue (200X) 


\subsection{Lung of the Fetuses}

\subsubsection{The Histopathological Observations}

Fetal pulmonary tissue of control group showed compact organization of bronchi, bronchioles and terminal bronchioles followed by specialized sac-like structures called alveoli lined with epithelium (Fig. F.1). Blood vessels and capillaries are normal in appearance. The fetal lung tissues of pregnant rats from both S1 and S2 groups were severely affected than maternal lung tissue and exhibited more extensive tissue damage, severely damaged bronchioles, alveolar hemorrhage and inflammatory cellular infiltration. The histopathological changes were increased in their severity in a dose dependent manner.

Fetal lung tissue of rats of S1 group showed congested alveolar septae, highly congested blood vessels which contained hemolysed blood cells (Fig. F.2). Fetal lung tissues of S2 group showed highly thickened alveolar septae, highly reduced alveolar sacs and thickened and corrugated epithelial layer of the bronchioles which lost their normal architecture and appeared with numerous pyknotic nuclei and highly distorted arterial wall which contained hemolysed blood cells whereas the hemosiderin granules were clearly appeared in the congested veins and arteries. The bronchiole lumen contained debris of degenerated epithelial cells (Figs. F. 3-4).

Mallory's trichrome stained sections of fetal lung tissue of the control group exhibited moderate distribution of the collagen fibers which were supporting the blood vessels, alveolar septae and the walls of the bronchioles (Fig. F.5). Increased collagen fibers were demonstrated in highly thickened and corrugated arterial and bronchial walls and in the interstitium between them in lung tissue of rats of groups S1, S2 in a dose dependent manner. The brightly stained red blood cells were commonly appeared inside the highly congested blood vessels (Figs. F. 6-7).

\subsubsection{The Histochemical Observations}

Moderate distribution of PAS +ve materials was seen in fetal lung tissue of control pregnant rat indicated by moderate staining affinity of the bronchial walls and alveolar septae (Fig. F.8). Decreased staining affinity of PAS +ve materials was detected in the thickened walls of bronchioles, walls of arteries and alveolar septae of fetuses lung tissue of rats of S1, S2 groups. But slightly increased staining affinity of polysaccharides was detected in red blood cells inside the congested blood vessels and hemorrhagic areas. Fibrous layers encircling walls of the bronchioles showed less dense staining affinity (Figs. F 9-10).

Fetal lung tissue of control group showed moderate distribution of the total protein content represented by deeply to moderately stained cells of the bronchial walls, alveolar septae and walls of the blood vessels (Fig. F. 11). Moreover, decreased staining affinity of total protein was noticed in the thickened and corrugated walls of the, blood vessels, bronchioles and alveolar septae of S1, S2 groups (Figs. F. 12-13). Fetal lung tissue of a control pregnant rat showed a slight deposition of amyloid $\beta$ in the lung tissue (Fig. F.14). Highly increased accumulation of amyloid $\beta$ material was realized in the highly thickened and corrugated walls of bronchioles, arteries and alveolar septae in the fetuses lung tissue of pregnant rats of S1,S2 


\section{Macrothink Institute $^{\mathrm{TM}}$}

groups (Figs. F. 15-17). Fetal lung tissue of control pregnant rats showed moderately stained DNA materials. Increased DNA materials was detected in the thickened alveolar septa and blood vessels while decreased DNA materials was noticed in the epithelial cells of thickened walls of bronchioles and some nuclei of degenerated cells in the bronchial lumens of fetuses of rats of S1, S2 groups .

\subsubsection{Immunohistochemical Observations}

Treatment of pregnant rats with carisoprodol produced intensive amount of Caspases- 3 in the fetuses pulmonary tissue of rats of S1, S2 groups (Figs. F.17, 18) compared to pulmonary tissue of control fetal group (Figs. F 16).

Table 1. Illustrating MOD values of both PAS +ve materials and total protein in the lung of control and S1\& S2 maternal and fetal groups

\begin{tabular}{c|c|c|c|c|c|c}
\hline & \multicolumn{6}{c}{ Mean $\pm \mathrm{SD}$} \\
\hline $\begin{array}{c}\text { PAS+ve } \\
\text { materials }\end{array}$ & $\begin{array}{c}\text { Maternal } \\
\text { Control }\end{array}$ & $\begin{array}{c}\text { Maternal } \\
\mathrm{S} 1\end{array}$ & $\begin{array}{c}\text { Maternal } \\
\mathrm{S} 2\end{array}$ & $\begin{array}{c}\text { Fetal } \\
\text { Control }\end{array}$ & $\begin{array}{c}\text { Fetal } \\
\mathrm{S} 1\end{array}$ & $\begin{array}{c}\text { Fetal } \\
\mathrm{S} 2\end{array}$ \\
\cline { 2 - 7 } & $1.31 \pm 0.003$ & $1.875 \pm 0.003$ & $1.4 \pm 0.002$ & $1.67 \pm 0.003$ & $\begin{array}{c}1.35^{* *} \pm 0.00 \\
4\end{array}$ & $1.60 \pm 0.001$ \\
& Maternal & Maternal & Maternal & Fetal & Fetal \\
potal & Control & $\mathrm{S} 1$ & $\mathrm{~S} 2$ & Control & S1 & Fetal 2 \\
\cline { 2 - 7 } & $0.78 \pm 0.001$ & $0.92 \pm 0.002$ & $0.87 \pm 0.01$ & $0.99 \pm 0.06$ & $0.83 \pm 0.002$ & $0.77 \pm 0.01$ \\
& & & & & & \\
\hline
\end{tabular}

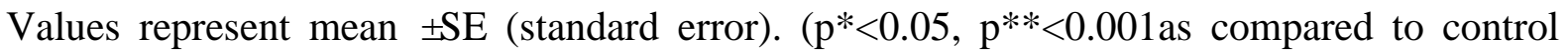
group)

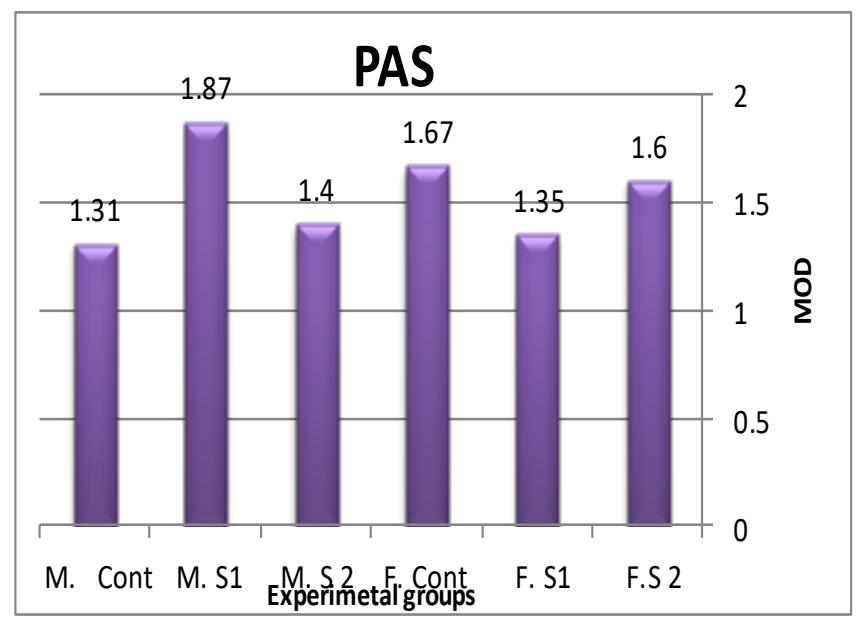

Histogram 1. Illustrating MOD values of PAS +ve materials lung of control and S1\&S2 treated groups 


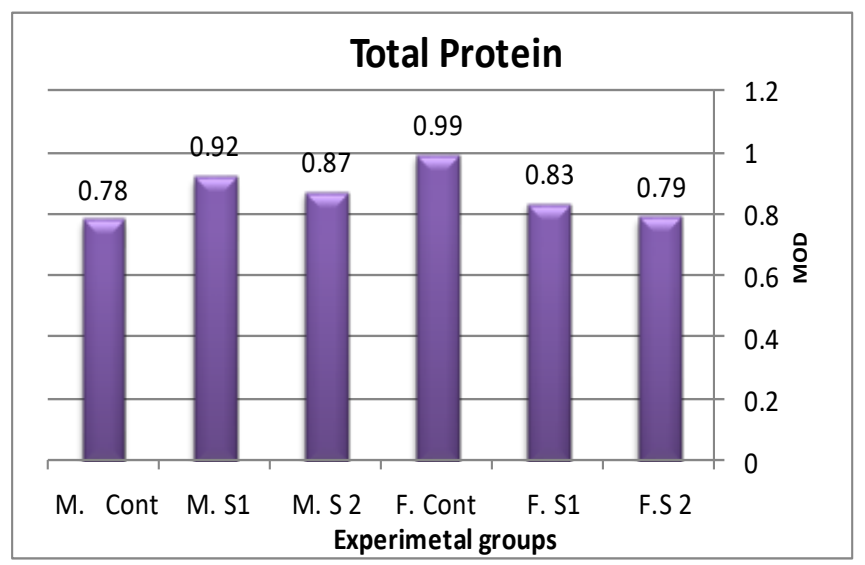

Histogram 2. Illustrating MOD values of total protein in lung of the control and S1\&S2 treated groups

Table 2. Showing MOD values of DNA content, amyloid $\beta$ protein and caspases-3 in the lung of the control and $\mathrm{S} 1 \& \mathrm{~S} 2$ treated groups

\begin{tabular}{|c|c|c|c|c|c|c|}
\hline & \multicolumn{6}{|c|}{ Mean \pm SD } \\
\hline \multirow[t]{2}{*}{$\begin{array}{c}\text { DNA } \\
\text { content }\end{array}$} & $\begin{array}{l}\text { Maternal } \\
\text { Control }\end{array}$ & $\begin{array}{l}\text { Maternal } \\
\text { S1 }\end{array}$ & $\begin{array}{l}\text { Maternal } \\
\text { S2 }\end{array}$ & $\begin{array}{c}\text { Fetal } \\
\text { Control }\end{array}$ & $\begin{array}{c}\text { Fetal } \\
\text { S1 }\end{array}$ & $\begin{array}{c}\text { Fetal } \\
\text { S2 }\end{array}$ \\
\hline & $1.78 \pm 0.003$ & $1.06 * * \pm 0.003$ & $1.13 * * \pm 0.001$ & $1.92 \pm 0.004$ & $1.25 \pm 0.01$ & $1.23 * * \pm 0.004$ \\
\hline \multirow[t]{2}{*}{$\begin{array}{l}\text { amyloid } \beta \\
\text { protein }\end{array}$} & $\begin{array}{l}\text { Maternal } \\
\text { Control }\end{array}$ & $\begin{array}{l}\text { Maternal } \\
\text { S1 }\end{array}$ & $\begin{array}{l}\text { Maternal } \\
\text { S2 }\end{array}$ & $\begin{array}{c}\text { Fetal } \\
\text { Control }\end{array}$ & $\begin{array}{c}\text { Fetal } \\
\text { S1 }\end{array}$ & $\begin{array}{c}\text { Fetal } \\
\text { S2 }\end{array}$ \\
\hline & $0.46 \pm 0.002$ & $0.94 \pm 0.002$ & $1.32 * * \pm 0.001$ & $0.57 \pm 0.007$ & $1.21 \pm 0.002$ & $1.19 \pm 0.001$ \\
\hline \multirow[t]{2}{*}{ Caspases-3 } & $\begin{array}{l}\text { Maternal } \\
\text { Control }\end{array}$ & $\begin{array}{l}\text { Maternal } \\
\text { S1 }\end{array}$ & $\begin{array}{c}\text { Maternal } \\
\text { S2 }\end{array}$ & $\begin{array}{c}\text { Fetal } \\
\text { Control }\end{array}$ & $\begin{array}{c}\text { Fetal } \\
\text { S1 }\end{array}$ & $\begin{array}{c}\text { Fetal } \\
\text { S2 }\end{array}$ \\
\hline & $0.82 \pm 0.007$ & $0.95 \pm 0.008$ & $1.014 \pm 0.0012$ & $0.68 \pm 0.12$ & $1.27 \pm 0.002$ & $1.59 \pm 0.002$ \\
\hline
\end{tabular}

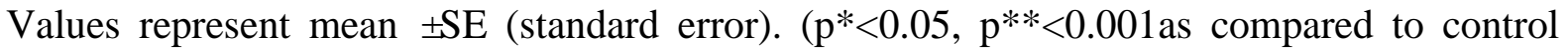
group) 


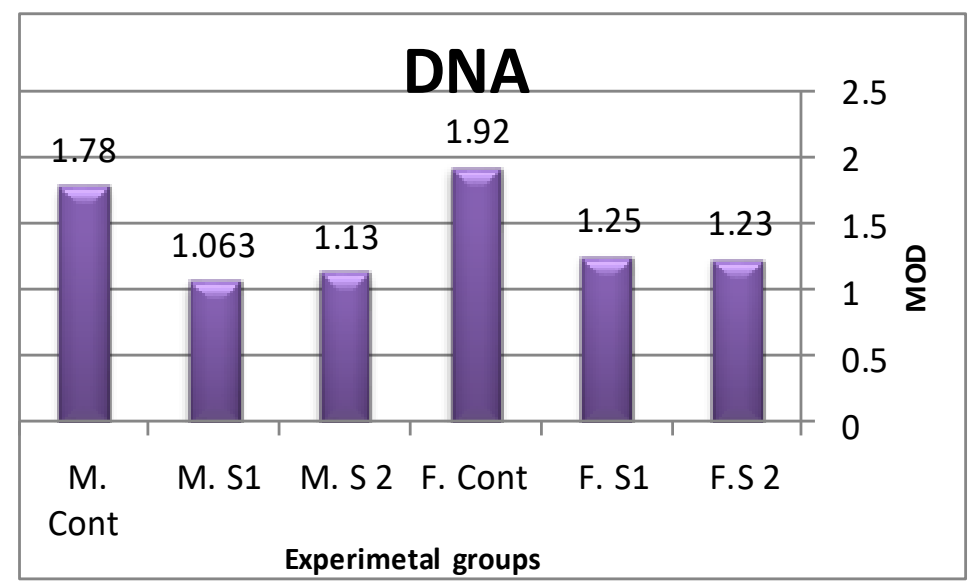

Histogram 3. Showing MOD values of DNA content in lung of the control and S1\&S2 treated groups

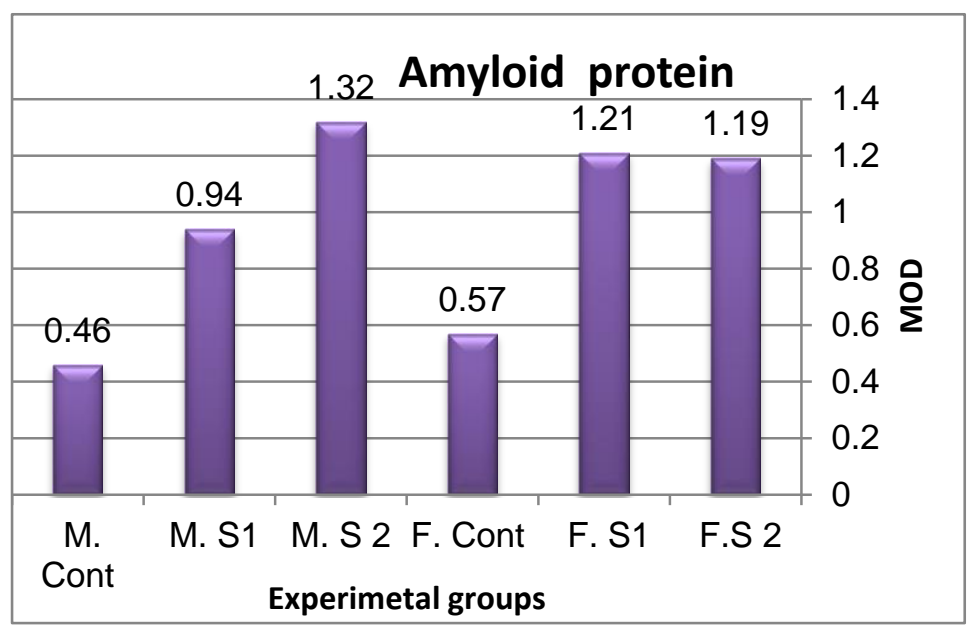

Histogram 4. Showing MOD values of amyloid $\beta$ protein in lung of the control and S1\&S2 treated groups

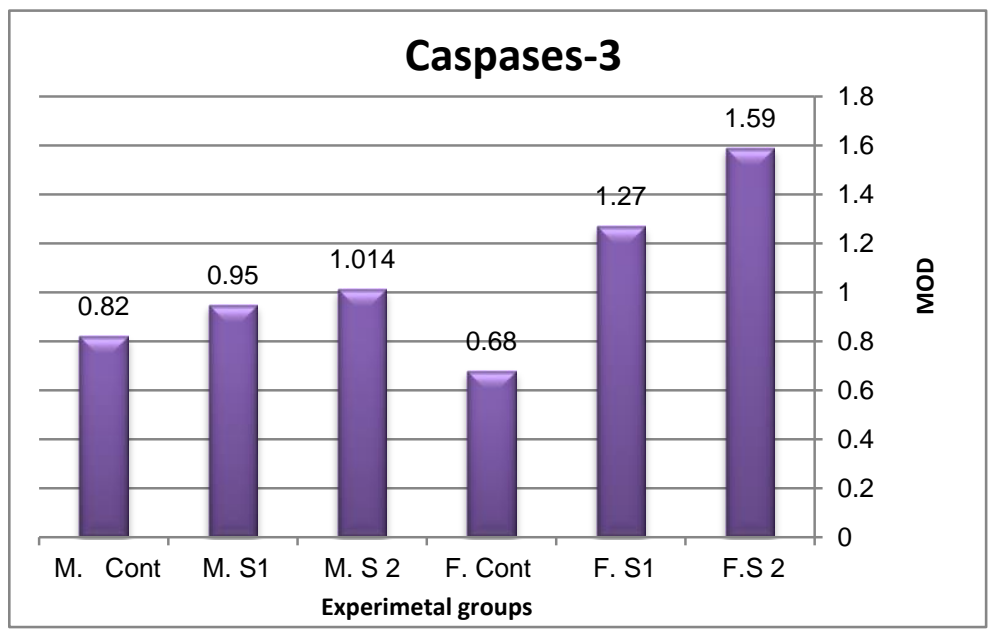

Histogram 5. Showing MOD values of caspases-3 in lung of the control and S1\&S2 treated groups 


\section{Macrothink}

Journal of Biology and Life Science ISSN 2157-6076 2020, Vol. 11, No. 1
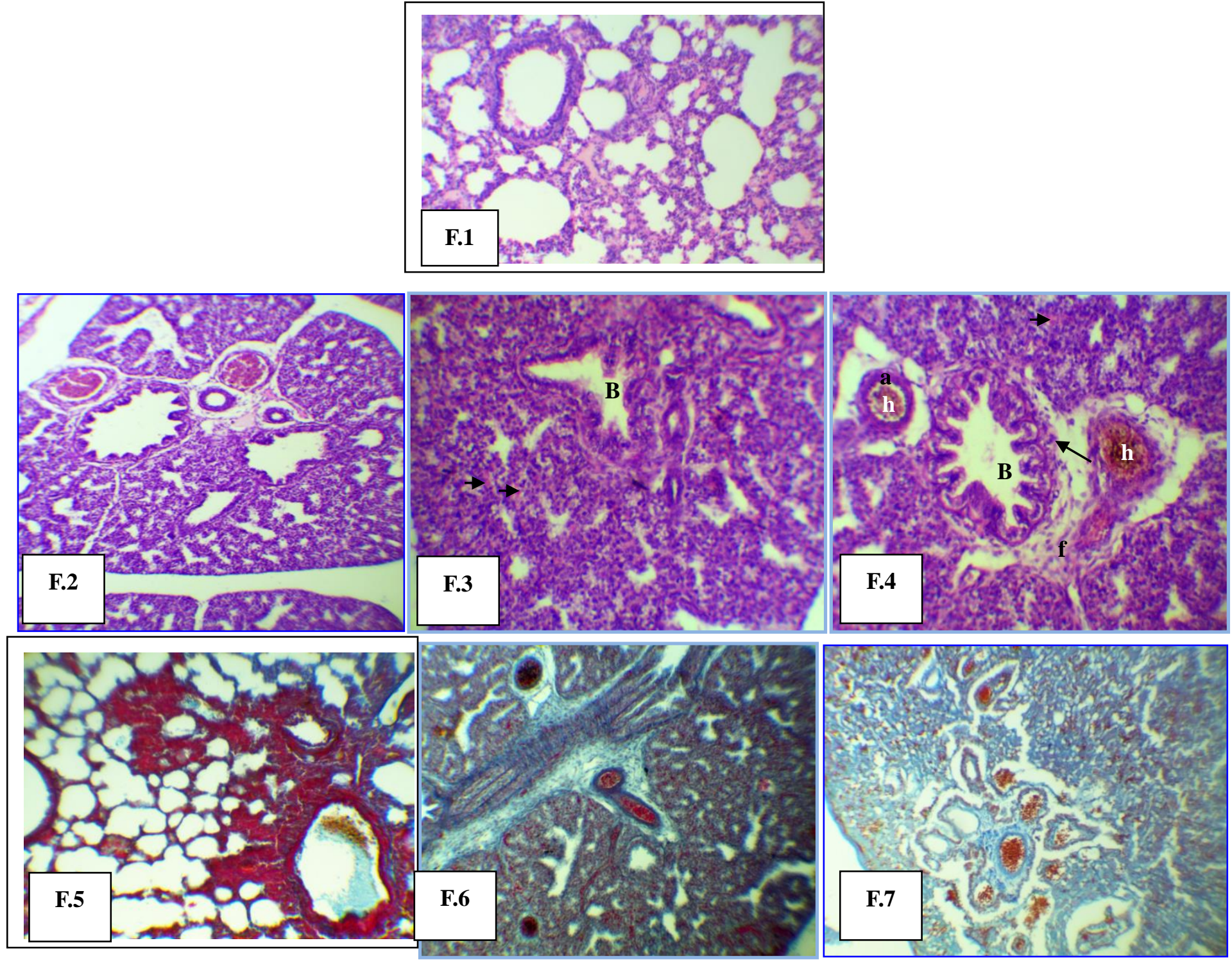

Figures F.1 -F.7. photomicrographs of sections of fetal lung tissue of control and S1\&S2 treated groups (x 100)

Fig.F.1: fetal lung tissue of a control rat showing normal architecture of bronchiole and fetus lung tissue and the Blood vessels and capillaries are normal in appearance (H \&E x 100).

Fig.F.2: fetal lung tissues of rat of S1 group showing loss of normal architecture of many bronchioles (B), which appeared with pyknotic nuclei in their thickened, corrugated and distorted epithelial cells. Notice: congested alveolar septae and highly congested blood vessels which contained hemolysed blood cells. The artery lumen was constricted due to the severely thickened arterial wall (H \&E x 100).

Fig.F.3: fetal lung tissues of rats of S2 group showing highly distorted and corrugated bronchioles (B), congested and highly thickened alveolar septae, highly reduced alveolar sacs, numerous hemorragic areas (arrow head) around the bronchiole and highly thickened wall of the congested blood vessels ( $\mathrm{H} \& \mathrm{E}$ x 100). 


\section{Macrothink}

Fig.F.4: fetal lung tissues of rats of S2 group showing thickened and corrugated epithelial layer of the bronchioles (B) which lost their normal architecture and appeared with numerous pyknotic nuclei $(\uparrow)$. Notice: thickened alveolar septae, distorted arterial wall (a) which contained hemolysed red blood cells. The bronchiole lumen contained debris of some degenerated epithelial cells. Fibrosis was noticed around wall of bronchiole (f) and the hemosiderin granules $(\mathrm{h})$ were clearly appeared in the congested veins and arteries $(\mathrm{H} \& \mathrm{E} \mathrm{X}$ 100).

Fig.F.5: fetal lung tissue of a control rat exhibiting normal slight distribution of collagen fibers in the fetal lung tissue of a control pregnant rat (Mallory's trichrome stain x 100).

Fig.F.6: fetal lung tissues of rat of S1 group showing increased collagen fibers in the fetal lung tissue. Notice: increased collagen fibers in walls of the bronchioles, alveolar septae, blood vessels and in the interstitium between them (Mallory's trichrome stain X 100).

Fig.F.7: fetal lung tissues of rats of S2 group showing highly increased collagen bundles in the highly corrugated and thickened walls of blood vessels, bronchioles, arteries and in the interstitium between them. Also, brightly stained RBCs were commonly appeared inside the highly congested blood vessels (Mallory's trichrome stain X 100). 


\section{$\Lambda$ Macrothink}

Journal of Biology and Life Science

ISSN 2157-6076

2020, Vol. 11, No. 1
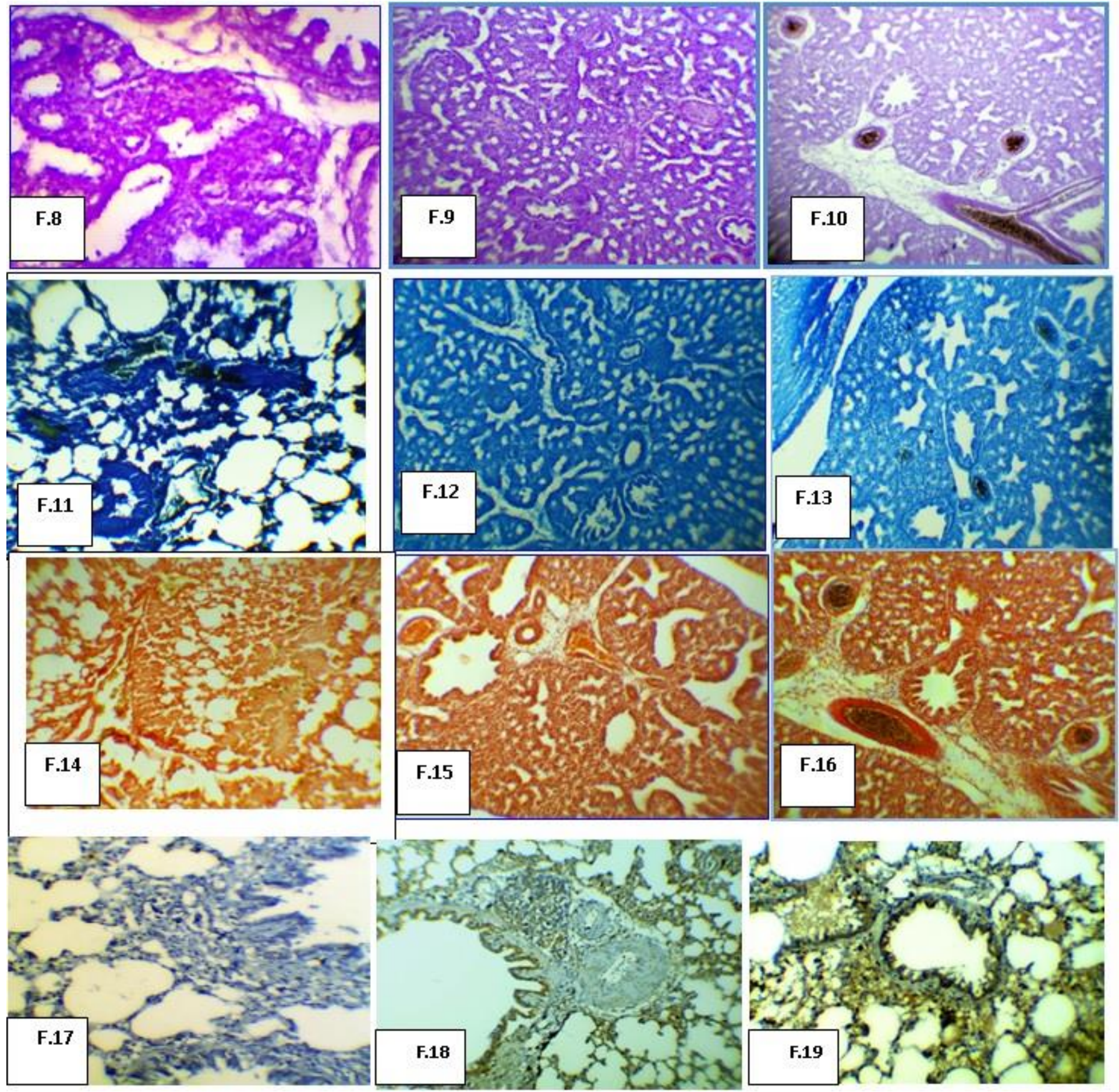

Figures F.8 -F.19. photomicrographs of sections of fetal lung tissue of the control and S1\&S2 treated groups (x 100, 200)

Fig.F.8: fetal lung tissue of a control rat illustrating moderate distribution of polysaccharides in fetal lung tissue of a control pregnant rat (PAS X100).

Fig.F.9: fetal lung tissues of rats of S1 group showing decreased polysaccharides. Notice: less dense staining affinity of polysaccharides in red blood cells inside congested blood vessels 
and hemorrhagic areas. The fibrous layers encircling bronchiole walls showed less dense staining affinity and the thickened alveolar septae showed less dense staining affinity (PAS $\mathrm{x} 100)$.

Fig.F.10: fetal lung tissues of rats of S2 group showing decreased polysaccharides in the tissue although less dense staining affinity of polysaccharides in wall of the thickened arterial wall of the fetal lung tissue due to increased RBCs and some bronchioles were appeared (PAS X100).

Fig.F.11: fetal lung tissue of a control rat showing moderate distribution of total protein in the fetal lung tissue (Mercuric bromophenol blue X 100).

Fig.F.12: fetal lung tissues of rats of S1 group showing decreased staining affinity of total protein in the highly congested arterial wall, in the highly thickened and corrugated walls of the bronchioles and alveolar septae (Mercuric bromophenol blue X 100).

Fig.F.13: fetal lung tissues of rats of S2 group showing decreased staining affinity of total protein in thickened walls of the bronchioles, in thickened alveolar septae. Notice: dark stained hemosiderin granules inside the blood vessels (Mercuric bromophenol blue X 100)

Fig.F.14: fetal lung tissue of a control rat showing slight deposition of amyloid $\beta$ in the lung tissue (Congo red stain X 200).

Fig.F.15: fetal lung tissues of rats of $\mathrm{S} 1$ group showing increased accumulation of amyloid $\beta$ material in walls of the highly corrugated and distorted bronchioles, arteries and alveolar septae in the tissue (Congo red stain X 100).

Fig.F.16: fetal lung tissues of rats of S2 group showing highly increased accumulation of amyloid $\beta$ material in the highly thickened walls of blood vessels, highly thickened bronchioles, alveolar septae and arteries in the tissue (Congo red stain X 100).

Figures F.17-19: photomicrographs of fetal lung tissues collected from pregnant control rats and pregnant rats of S1, S2 groups stained with Caspases-3-immune-staining.

Fig.F.17: fetal lung tissue of a control rat showing scarce solitary nuclear immunoreactivity for caspase-3 indicated by very faint brown (X 200). Figs.F.18-19: fetal lung tissues of rats of S1 and S2 group showing marked increase in the caspase- 3 amount indicated by more dense brown staining affinity in the lung tissue (X 200).

\section{Discussion}

Carisoprodol (Soma) is a commonly specified central muscle relaxant, but it is also subject to perversion or abuse (Reeves \& Burke, 2010). Carisoprodol has been indicated to induce some adverse effects on human health and considered by some to be rarely fatal (Robertson \& Marinetti, 2003). Scant reports are available about histopathological effects of carisoprodol drug particularly in the lung tissue.

Over dosage of carisoprodol commonly produces CNS depression, coma, hypotension, blurred vision, respiratory depression and Death. The effects of carisoprodol overdose and 
other CNS depressants such as opioids, benzodiazepines, alcohol, and tricyclic antidepressants can be collective even when one of the drugs has been used in the recommended dosage therefore, more vigilance should be considered with the patient people who take more than one of these CNS depressants simultaneously. Fatal overdoses of carisoprodol have been reported alone or in combination with CNS depressants (Witenko et al., 2014). In the present study, carisoprodol treatment of pregnant rats with the two current doses S1\&S2 induced many dystrophic changes which increased in their severity in a dose dependent manner. Numerous histopathological changes represented by extensive tissue damages, numerous necrotic areas, narrow alveolar sacs with highly thickened alveolar septae, alveolar hemorrhage, severely damaged bronchioles, highly thickened walls of blood vessels, most of them are congested with hemolyzed blood cells and cellular infiltration in the lung tissues. Such findings come in agreement with those reported by Awadalla \& Salah-Eldin (2016) who revealed that tramadol, like other opioids induced intensive histopathological changes in lung tissue of rats and induced decreased antioxidant plasma levels indicating failure of antioxidant defense mechanism against oxidative damage. According to Faria et al. (2017), both of tapentadol and tramadol (CNS depressants) were found to cause severe cellular damage, inflammatory cellular infiltrations and cell death in the pulmonary tissues although tapentadol induced more damage than tramadol.

Moreover, the fetal lung tissues of the both groups S1 and S2 in the current study were highly affected than maternal lung tissue and exhibited more extensive tissue damage, severely damaged bronchioles, alveolar hemorrhage and inflammatory cellular infiltration. The histopathological changes were increased in their severity in a dose dependent manner. Fetal lung tissues of S2 group showed highly reduced alveolar sacs, highly thickened alveolar septae, and corrugated and thickened epithelial layer of the bronchioles which lost their normal architecture and appeared with numerous pyknotic nuclei. Moreover, highly distorted arterial wall were clearly appeared and the hemosiderin granules were clearly appeared in the congested blood vessels.

In accordance with some previous studies, the treatment of pregnant rats with carisoprodol caused numerous degenerative changes in the liver and esophagus tissues of the pregnant rats and their fetuses (Abouel-Magd, 2018 and Abd Rabou, 2019). Such severe histopathological changes with carisoprodol treatments may be due to oxidative stress and subsequent overproduction of reactive oxygen species (ROS) which was postulated as most important mechanism of toxicity (Rajapakse et al., 2007).

Also previous researches reported that, the increased production of reactive oxygen species (ROS) lead to pulmonary toxicity, and eventually lung fibrosis. Also, ROS have been indicated to activate profibrotic transforming growth factor- $\beta$ (TGF- $\beta$ ) in the lung that induces the development of inflammation and induces the proliferation of the fibroblasts leading to severe pulmonary fibrosis (Kliment \& Oury, 2010 and Shi et al., 2014). Katsuyama et al. (2012) reported that ROS are generated by NADPH oxidase or mitochondrial electron transport chain in cells and are implicated in differentiation and proliferation of cells and stability of genome. Ostrovsky et al. (2009) demonstrated oxidative stress and ROS stimulate cellular damage comprising apoptosis and DNA fragmentation. Dilated and congested blood 
vessels were realized in the present experiment and this may be due to increased pulse pressure of pulmonary arteries (Abuo El Naga \& Abd Rabou, 2012). Also, the appearance of degenerated alveolar septae and debris of degenerated cells in the lung bronchioles may be related to of DNA effects in the nuclei of their cells (Zhang et al., 2006). Moreover, Van der Kleijn (1969) indicated that the radiolabeled carisoprodol was taken up by the central nervous system of mice within forty seconds after intravenous injections of it, it distributed throughout the body within ten minutes, the highest concentrations were found in the lung, liver, pituitary gland, myocardium and adrenal cortex followed by the blood and skeletal muscles. In agreement with the present study, through histopathological studies, carisoprodol treatment of pregnant rats caused severe dystrophic changes included large hemorrhagic areas, highly congested blood vessels and numerous necrotic areas in liver tissue of both maternal and fetal tissues (Abouel-Magd, 2018).

The results of the current study showed increased collagen fibers in the highly thickened and corrugated walls of blood vessels, thickened arteries, around walls of the bronchioles and in the interstitium between them in the lung tissues. Increased collagen fibers in the current work come in coincidence with those reported before areas (Abd El-Hady \& Al Jalaud, 2015 and Abouel-Magd, 2018) .Such increase in collagen fibers deposition might lead to rapid healing process where increasing secretion of collagen subtype within the site of injury lead to replacing of necrotic tissue during the proliferative phase of the wound healing mechanism (Suvik \& Effendy, 2012). The increased collagen fibers may lead to increase the defense reaction against toxic materials (Mansour et al., 2013). Increased collagen deposition may be due to oxidative stress that stimulates the expression of genes involved in collagen biosynthesis (Guler et al., 2009). Moreover, inhibition of superoxide dismutase (antioxidant enzyme) stimulates collagen production and this demonstrated a vital role of superoxide dismutase and the generated reactive oxygen species (ROS) in collagen accumulation (Lijnen et al., 2011). Results of the current study revealed increased PAS +ve materials in the thickened walls of bronchioles, arteries and alveolar septae with moderately stained granuloma areas in lungs of pregnant rats of groups S1, S2 and revealed decreased PAS +ve materials in the fetuses of S1, S2 groups in a dose dependent manner as compared to control group. Such increasing PAS +ve materials inside walls of bronchioles, blood vessels, alveolar septae may be due to increased thickness of these components or may be due to the increase in the RBCs after toxicity as reported with Abuo El Naga \& Abd Rabou (2012) and Abd El-Hady \& Al Jalaud (2015). The decreased carbohydrate contents in the fetal groups of the current study may be due to the increased stress on the organs which leading to consuming high energy to equalize the pressure upon them. Also, it may be related to hydrolytic enzymes realizing from ruptured lysosomes under toxic agents effects (Farrag \& Shelby, 2007). The current results showed increased staining affinity of total protein content in the thickened and corrugated walls of the bronchioles, blood vessels and alveolar septae in the lung tissue of S1\& S2 pregnant rats but showed decreased staining affinity of total protein in their fetuses as compared to control group.

Generally, increased staining affinity of total protein may be attributed to the generation of ROS and consequent oxidative stress (Suman et al., 2013). Increased total protein content of 
lung tissue due to toxicity was also recorded before by Abd El-Hady \& Al Jalaud (2015) who declared that the increase in staining affinity of total protein of lung tissues following toxicity may be attributed to increase red blood cells (RBCs) in the congested blood vessels and also to increased collagen fibers deposition.

On the other hand, Abuo El Naga \& Abd Rabou (2012) stated that the decreased protein content may be due to rupture of cellular organelles or to decreased ribosomes. Abdel-Meguid et al. (2012) stated that the decrease in protein content may be due to lysosomal membranes disruption under the effects of various toxicants which leads to releasing of their hydrolytic enzymes in the cytoplasm which causing dissolution and lysis of the target material within the cytoplasm.

In accordance with Abouel-Magd (2018), the current study showed reduced DNA materials in most nuclei of maternal lung tissue from S1and S2 groups. Also, decreased DNA materials were realized in most fetal lung tissue of S1 and S2 groups.

The decrease in DNA content in the current study may be due to use it to build up new cells or enzymes or due to arrested metabolism to reduce the stress or due to disruption of lysosomal membranes (Sakr and Shalaby, 2011). Degenerated epithelium in the bronchioles observed in the present study may be due to highly affected DNA in the nuclei of their cells. Moreover, decreased DNA content may be due to production of active oxygen which lead to oxygen pressure and increased free radicals which affect DNA chains that lead to cancer (Abuo El Naga \& Abd Rabou, 2012).

The current study illustrated an increase in the amyloid- $\beta$ deposits in maternal and fetal lung tissue of S1, S2 groups in the arterial walls, bronchioles, alveolar septae, hemolysed blood cells and necrotic areas in the lung tissue.

Amyloid proteins are insoluble fibrous protein structures having specialized structural traits and arise from about eighteen inappropriately folded versions of proteins and polypeptides present naturally in the body (Ramirez-Alvarado et al., 2000). Amyloids have been associated with the pathology of more than twenty severe human disorders since abnormal accumulation of amyloid fibrils in organs may play a role in various neurodegenerative diseases and may lead to amyloidosis (Pulawski et al., 2012). Kadowaki (2005) showed that amyloid accumulation is associated with dysfunction of mitochondria and may lead to generation of reactive oxygen species (ROS), which can induce a signaling pathway leading to apoptosis or programmed cell death. The Caspase- 3 is the main executioner of programmed cell death concerned in cleavage of many apoptosis related proteins. The cleavage of many apoptosis related proteins by activated caspase- 3 provides one of the most utilize diagnostics for inducing of apoptosis in most cell type (Cohen, 1997).

The current study produced intensive amount of Caspases- 3 in the pulmonary tissue of maternal and fetal S1, S2 groups in the arterial walls, bronchioles, alveolar septae, in the lung tissue which indicates severe apoptosis. These results were consistent with other studies on CNS depressants or analgesic drugs as Gloor et al. (2019) who stated that acetaminophen drug has been demonstrated to cause cell apoptosis and necrosis, mitochondrial damage and 
Jaeschke (2015) who added that acetaminophen or paracetamol, which is considered a safe drug at therapeutic dose can cause severe hepatic damage, acute liver failure and cell death after overdoses. Camargo et al. (2016) reviewed the major pathways for apoptosis after ethanol (CNS depressants) exposure and suggested that, the ethanol exposure has a major effect on the degree of apoptosis in the central nervous system. They revealed the presence of widespread pro-antiapoptotic responses and indicating that although apoptosis is increased, there are also cellular attempts to compensate and overcome the exposure.

\section{Conclusion}

The present study confirmed the risk of increased pulmonary damage in both maternal and fetal lung tissues due to carisoprodol treatment and indicated the higher risk of carisoprodol especially with high doses. Although carisoprodol compound is recommended to be more effective in relief muscle pain, its toxicity should be kept in mind and more cautions must be taken in considerations with its usage in treatments.

\section{Acknowledgement}

Thanks for Prof. Dr Fatma Ahmed Eid, Professor of Histology and Histochemistry, Faculty of Science, Al-Azahar University.

\section{References}

Abd El-Hady, A., \& AlJalaud, N. (2015). Therapeutic Effects of Olive Leaf Extract or Bone Marrow Mesenchymal Stem Cells against Lung Damage Induced In Male Albino Rats Exposed To Gamma Radiation. The Egyptian Journal of Hospital Medicine, 61, 685-699. https://doi.org/10.12816/0018770

Abd Rabou, M. A. (2019). Histological and histochemical alterations induced in rats fetal esophageal tissue intoxicated maternally with carisoprodol .The Egyptian Journal of Hospital Medicine, 75(2), 2254-2260.

Abdel-Meguid, N. E., Chmaisse, H. N., \& Abouzeinab, N. S. (2012). Silymarin ameliorates Cisplatin-induced hepato-toxicity in rats: histopathological and ultrastructural studies. J. Biol. Sci., 13, 463-479. https://doi.org/10.3923/pjbs.2010.463.479

Abdel-Wahab, B. A., \& Metwally, M. E. (2015). Clozapine-induced cardiotoxicity: role of oxidative stress, tumour necrosis factor alpha and NF- $\kappa \beta$. Cardiovascular toxicology, 15, 355-365. https://doi.org/10.1007/s12012-014-9304-9

Abouel-Magd, M. (2018). Maternal and fetal toxicity of carisoprodol. The Egyptian Journal of Hospital Medicine, 71(1), 2322-2350. https://doi.org/10.12816/0045310

Abuo El Naga, N. A., \& Abd Rabou, M. A. (2012). The possible protective role of bone marrow transplantation on irradiated mothers and their fetuses. Stem Cell, 3(3), 8-30.

Anwar, K., Salih, L., \& Abdulkareem, S. (2017). Histo-physiological study of some parts of organs treated with somadril drug. Journal of Raparin University, 4(11), 33-44. 
Awadalla, E., \& Salah-Eldin, A. (2016). Molecular and histological changes in cerebral cortex and lung tissues under the effect of tramadol treatment. Biomedicine \& Pharmacotherapy, (82), 269-280. https://doi.org/10.1016/j.biopha.2016.04.024

Ballet, F. (2015). Preventing drug-induced liver injury: how useful are animal models? Diges. Dis, 33(4), 477-485. https://doi.org/10.1159/000374093

Bancroft, J., \& Gamble, A. (2008). Theory and practice of histology techniques. (6 ${ }^{\text {th }}$ ed.) Churchill Livingstone. New York. London. p. 83-92.

Bramness, J. G., Buajordet, I., \& Skurtveit, S. (2008). The role of pharmaco-epidemiological studies in the market withdrawal of carisoprodol (Somadril) in Europe. Norsk. Epidemiologi, 18(2), 167-172. https://doi.org/10.5324/nje.v18i2.29

Camargo, M., Patrick, B., Cherry, I., \& Frank, A. (2016). Alcohol Intake and Apoptosis: A Review and Examination of Molecular Mechanisms in the Central Nervous System. Molecular Aspects of Alcohol and Nutrition. The Molecular Nutrition Series, 45-61. https://doi.org/10.1016/B978-0-12-800773-0.00004-5

Cohen, G. M. (1997). Caspases: the executioners of apoptosis. Biochemical Journal, 326, 1 -16. https://doi.org/10.1042/bj3260001

Drury, R., \& Wallington, E. (1980). Carleton's Histological Technique. (4th ed.). Oxford. Univ. Press. NewYork.

Faria, J., Barbosa, J., Leal, S., Afonso, P., Lobo, J., Moreira, R., ... Oliveira, D. (2017). Effective analgesic doses of tramadol or tapentadol induce brain, lung and heart toxicity in Wistar rats. Toxicology, (385), 38-47. https://doi.org/10.1016/j.tox.2017.05.003

Farrag, A. H., \& Shalby, S. E. (2007). Comparative histopathological and histochemical studies on IGR, lufenuron and profenofos insecticide albino rats. J. Appl. Sci. Res., 3(5), 377-386.

Gloor, Y., Schvartz, D., \& Samer, C. (2019). Old problem, new solutions: biomarker discovery for acetaminophen liver toxicity. Expert Opin Drug Metab Toxicol., 15(8), 659-669. https://doi.org/10.1080/17425255.2019.1642323

Guler, G., Turkozer, Z., Ozgur, E., Tomruk, A. \& Seyhan, N. (2009). Protein oxidation under extremely low frequency electric field in guinea pigs. Effect of $\mathrm{N}$-acetyl-L-cysteine treatment. Gen. Physiol.Biophys., 28, 47-55. https://doi.org/10.4149/gpb_2009_01_47

Jaeschke, H. L. (2015). Acetaminophen: Dose-Dependent Drug Hepatotoxicity and Acute Liver Failure in Patients. Dig Dis., 33(4), 464-471. https://doi.org/10.1159/000374090

Kadowaki, H. (2005). Amyloid beta induces neuronal cell death through ROS-mediated ASK1 activation. Cell Death Differ., 12(1), 19-24. https://doi.org/10.1038/sj.cdd.4401528

Kathy, T. V, Howard, H., Craig, G., Smollin, M., Neal, L., \& Benowitz, M. (2017). Severe carisoprodol withdrawal after a 14-year addiction and acute overdose. The Journal of Emergency Medicine, 52(5), 680-683. https://doi.org/10.1016/j.jemermed.2016.11.015 
Katsuyama, M., Matsuno, K., \& Yabe-Nishimura, C. (2012). Physiological Roles of NOX/NADPH Oxidase, the Superoxide-Generating Enzyme. Journal Clinical Biochemistry Nutrition, 50, 9-22. https://doi.org/10.3164/jcbn.11-06SR

Kiernan, J. A. (1981). Histological and histochemical methods, theory and practice. Pergamon Press. New York, USA.

Kliment, C. R., \& Oury, T. D. (2010).Oxidative stress, extracellular matrix targets, and idiopathic pulmonary fibrosis. Free Radic Biol Med., (49), 707-717. https://doi.org/10.1016/j.freeradbiomed.2010.04.036

Kumar, M., \& Dillon, G. H. (2016). Assessment of direct gating and allosteric modulatory effects of meprobamate in recombinant GABA A receptors. European J. Pharmacol., 775, 149-158. https://doi.org/10.1016/j.ejphar.2016.02.031

Lijnen, P., Prihadi, J. S., Van-Pelt, J. F., \& Fagard, R. H. (2011). Modulation of reactive oxygen species and collagen synthesis by angiotensin II in cardiac fibroblasts. The Open Hypertension J., 4, 1-17. https://doi.org/10.2174/1876526201104010001

Mansour, M., Ibrahim, M., \& Mahmoud, H. (2013). The Possible Protective Role of Bone Marrow Transplantation against Alternations Induced by Gamma Radiations on heart of Pregnant Albino Rats and Their Fetuses. Journal of biology and life science, 4(1), 247-272. https://doi.org/10.5296/jbls.v4i1.3245

Mclntyre, I. M., Sherrard, J., \& Lucas, J. (2012). Postmortem carisoprodol and meprobamate concentrations in blood and liver: lack of significant redistribution. J. Anal. Toxicol., 36(3), 177-181. https://doi.org/10.1093/jat/bks011

Naresh, N., Munish A., Surendra, K., Mattoo, M., \& Debasish, B. (2013). Carisoprodol: an under recognized drug of abuse in north India. General Hospital Psychiatry., 35(1), 89-92. https://doi.org/10.1016/j.genhosppsych.2012.07.011

Ostrovsky, S., Kazimirsky, G., Gedanken, A., \& Brodie, C. (2009). Selective Cytotoxic Effect of $\mathrm{ZnO}$ Nanoparticles on Glioma Cells. Nano Research, (2), 882-890. https://doi.org/10.1007/s12274-009-9089-5

Paget, G. E., \& Barnes, J. M. (1964). Interspecies dosage conversion scheme in evaluation of results and quantitative application in different species. In: Laurence, D. R. \& Bacharach, A. L. (Eds.), Evaluation of Drug Activities (pp: 160-162). London and USA: Academic Press.

Pearse, A. G. (1972). Histochemistry, Theoretical and applied (3th ed.), Vol. 1. Churchill Livingstone. London.

Pulawski, W., Ghoshdastider, U., Andrisano, V., \& Filipek, S. (2012). Ubiquitous amyloid. Applied Biochem. Biotechnol., 166(7), 1626-1643. https://doi.org/10.1007/s12010-012-9549-3

Rajapakse, N., Kim, M. M., Mendis, E., \& Kim, S. K. (2007). Inhibition of free radical-mediated oxidation of cellular biomolecules by carboxylated chitooligosaccharides. Bioorg. Med. Chem., 15(2), 997-1003. https://doi.org/10.1016/j.bmc.2006.10.030 
Ralph, L. M., Look, W., Wheeler, S., \& Sacks, H. (2008). Double-blind, placebo-controlled trial of carisoprodol $250-\mathrm{mg}$ tablets in the treatment of acute lower-back spasm. Current Medical Research and Opinion, 24(2), 551-558. https://doi.org/10.1185/030079908X261014

Ramirez-Alvarado, M., Merkel, J., \& Regan, L. (2000). A systematic exploration of the influence of the protein stability on amyloid fibril formation in vitro. PNAS., 97(16), 8979-8984. https://doi.org/10.1073/pnas.150091797

Reeves, R. R., \& Burke, R. S. (2010). Carisoprodol: abuse potential and withdrawal syndrome. Curr. Drug Abuse Rev., 3(1), 33-38. https://doi.org/10.2174/1874473711003010033

Reeves, R., Burke, R., \& Kose, S. (2012). Carisoprodol: update on abuse potential and legal status. Southern Medical Journal, 105(11), 616-623. https://doi.org/10.1097/SMJ.0b013e31826f5310

Robertson, M. D., \& Marinetti, L. J. (2003). Carisoprodol effects on human performance and behavior. Forensic Science Reviews, (15), 1-9.

Rust, G. S., Hatch, R., \& Gums, J. G. (1993). Carisoprodol as a drug of abuse. Arch. Fam. Med., 2, 429-435. https://doi.org/10.1001/archfami.2.4.429

Sakr, S. A., \& Shalaby, S. Y. (2011). Ginger extract protects metalaxyl-induced histomorphological and histochemical alterations in testes of albino mice. J. Appl. Pharm. Sci., l(10), 36-42.

Shi, K., Jiang, J., Ma, T., Xie, J., Duan, L., Chen, R., ... Zheng J. (2014). Pathogenesis pathways of idiopathic pulmonary fibrosis in bleomycin-induced lung injury model in mice. Respir Physiol Neurobiol., (190), 113-117. https://doi.org/10.1016/j.resp.2013.09.011

Simon, S., Carrie, D., Andrea, W. J., Wheeler, P., \& Harry, S. (2010). Bioavailability of oral carisoprodol 250 and $350 \mathrm{mg}$ and metabolism to meprobamate: A single-dose=crossover study. Current Therapeutic Research, 71(1), 50-59. https://doi.org/10.1016/j.curtheres.2010.02.003

Suman, S., Rodriguez, O., Winters, T., Fornace, J., Albanese, C., \& Datta, K. (2013). Therapeutic and space radiation exposure of mouse brain causes impaired DNA repair response and premature senescence by chronic oxidant production. AGING, 5(8), 607-622. https://doi.org/10.18632/aging.100587

Suvik, A., \& Effendy, A. W. (2012). Staining in collagen evaluation in wound healing study. Malaysian J. Vet. Res., 3(1), 39-47.

Valle, S. (1986). Special stains in microwave oven. J. Histotechnol., 9, 237-248. https://doi.org/10.1179/his.1986.9.4.237

Van der, K. E. (1969). Kinetics of distribution and metabolism of ataractics of the meprobamate-group in mice. Arch. Int. Pharmacodyn. Ther., 178, 457-480.

Witenko, C., Moorman-Li, R., Motycka, C., Duane, K., Hincapie-Castillo, J., Leonard, P., \& Valaer, C. (2014). Considerations for the appropriate use of skeletal muscle relaxants for the management of acute low back pain. Phar. Thera., 39(6), 427-435. 


\section{Macrothink}

Zhang, D., Xu, Z., Chiang, A., Lu, D., \& Zeng, Q. (2006). Effect of GSM $1800 \mathrm{MHz}$ radiofrequency EMF on DNA damage in Chinese hamster lung cells. Zhonghuo Nei. Ke. Za. Zhi., 36(3), 183-186.

\section{Copyright Disclaimer}

Copyright for this article is retained by the author(s), with first publication rights granted to the journal.

This is an open-access article distributed under the terms and conditions of the Creative Commons Attribution license (http://creativecommons.org/licenses/by/3.0/). 